\title{
Leptophlebiidae (Insecta: Ephemeroptera) from Gorgona Island National Natural Park (Tropical Eastern Pacific, Colombia) with the description of two new species
}

\author{
María del Carmen Zúñiga ${ }^{1}$, Carlos Molineri $^{2 *}$, Eduardo Domínguez ${ }^{2}$ and William Cardona ${ }^{1}$ \\ ${ }^{1}$ Grupo de Investigaciones Entomológicas, Departamento de Biología, Universidad del Valle, Cali, Colombia \\ 2 Instituto de Biodiversidad Neotropical-CONICET, Facultad de Ciencias Naturales, Universidad Nacional de Tucumán, Argentina
}

Received 12 June 2015; Accepted 30 August 2015

\begin{abstract}
Gorgona National Natural Park comprises Gorgona and Gorgonilla Islands, located in the Colombian Pacific at $35 \mathrm{~km}$ from mainland. A large-scale study was conducted in Gorgona including samples from benthos and aereal nets and traps during five fieldworks. We here focus on the family Leptophlebiidae, describing two new species and giving data of four additional species. Terpides iguapoga sp. n. is described and illustrated from nymphs and adults, and can be characterized by the following characters, in the nymph: fore trochanter and femur with row of strong spine-like setae on inner margin, gills with blackish tracheae, posterolateral projections present on terga VI and VIII-IX; in the adult: upper portion of eyes orangeish white, forewing membrane hyaline tinged with yellowish around crossveins and marginal intercalary veins, genitalia with penes abruptly narrowing on distal third. Thraulodes insular sp. n. is described from nymphs and adults and diagnosed as follows, in the nymph: abdominal gills with narrow lamellae, femora with black streak near apex; in the imago: forewing costal area basal to bulla without crossveins, a spot and a band on femora, terga II-VI translucent white, terga VII-X darker, posterior margin of subgenital plate triangular, penes spines short and robust. We give new geographic records for four additional species: Farrodes caribbianus, Farrodes roundsi, Hagenulopsis esmeralda and Hagenulopsis zunigae. Ecological data and distributional maps are provided. Leptophlebiidae presents a reduced diversity in relation to mainland; in general the species recorded show a geographic relation to the Chocoan-Caribbean and Andean mayfly faunas.
\end{abstract}

Key words: Terpides / Thraulodes / Farrodes / Hagenulopsis / mayfly

\section{Introduction}

Emergent land at the Gorgona National Natural Park (NNP) comprises Gorgona and Gorgonilla Islands; both represent the largest insular area from the Colombian Pacific. Considered a continental insular formation, it is separated from mainland by $35 \mathrm{~km}$ of open sea, with depths of less than $120 \mathrm{~m}$ (Giraldo, 2012; Giraldo et al., 2014). Different land uses are known through its history, including a high-security prison, but from 1984 this territory was declared a NNP, and together with the marine ecosystems in the vicinity of the islands forms one of the largest marine protected areas in the region. The area is located in the Chocó biogeographical Province (Neotropical Region, Caribbean Subregion,

*Corresponding author: carlosmolineri@gmail.com
Morrone, 2001), with a land extension of 1431.28 ha and a maximum altitude of $338 \mathrm{~m}$.

Scientific research in Gorgona NNP has focused on plants, mammals and birds but works on the abundance, richness, diversity and distribution of insects are scarce (Longo-Sánchez and Blanco, 2014; Zúñiga et al., 2014). The extreme pluviosity, around $6000 \mathrm{~mm}$ in a year, and annual evapotranspiration rate of $1500 \mathrm{~mm}$ cause a positive net hydric balance. This situation allows the existence of more than 25 permanent creeks in the Gorgona Island, with discharges of 30-300 L.s ${ }^{-1}$ (Giraldo et al., 2014).

Running waters from Gorgona are low-order streams, with some biogeochemical and nutrient variations, but all are of good sanitary and environmental quality, transparent, oxygen saturated, with low levels of nitrogen and dissolved $\mathrm{CO}_{2}$, but with a relatively high content of minerals driving elevated values of specific conductivity (Vásquez et al., 1996; Blanco, 2009). 


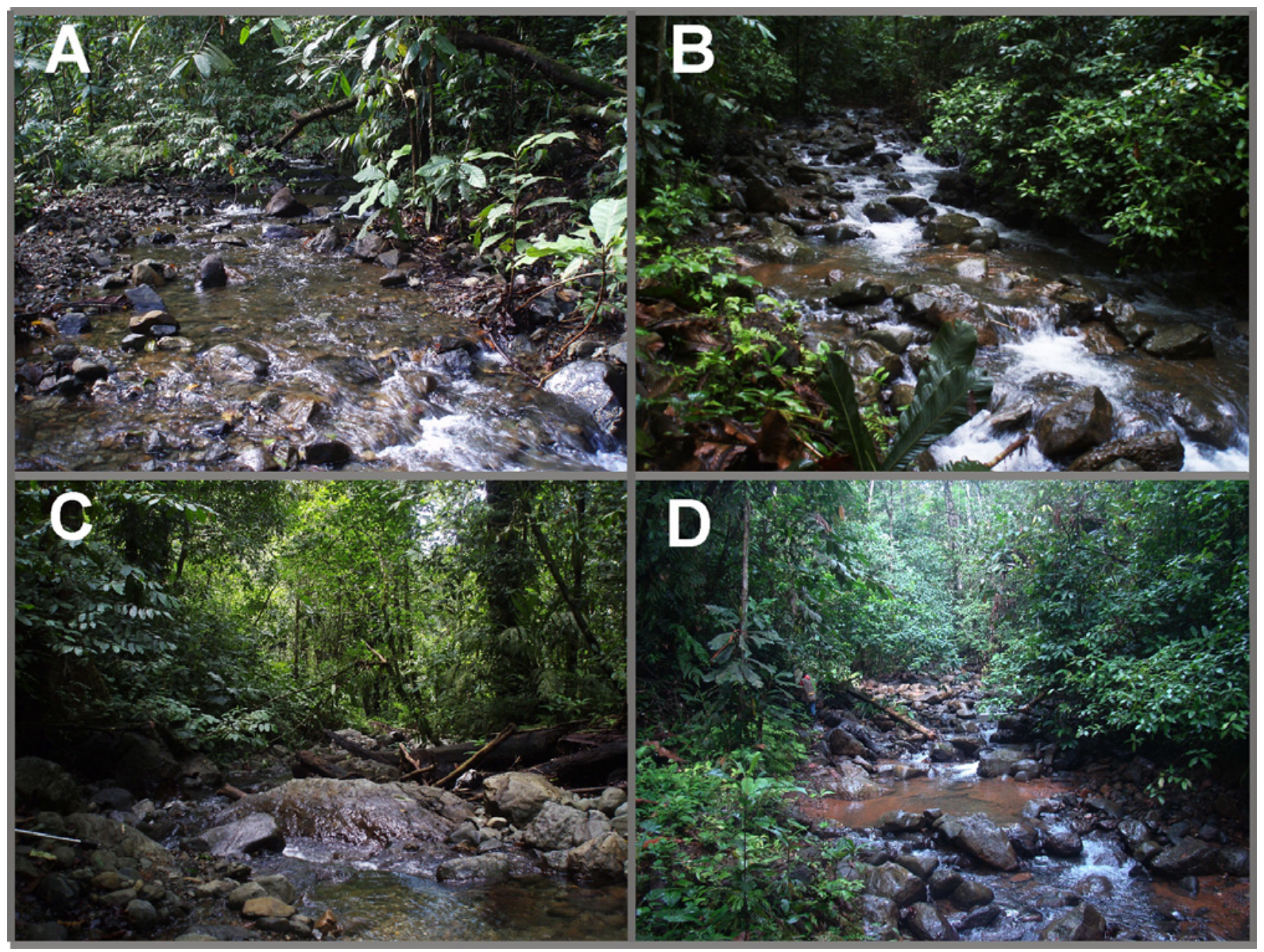

Fig. 1 A-D: Creeks in Gorgona National Natural Park. A: Quebrada Iguapoga, Sendero Cerro Trinidad; B: Quebrada Chorro del Cura, Sendero Cerro Trinidad; C: Quebrada Ilu, Sendero del Acueducto; D: Quebrada Pizarro, Sendero Playa Yundigua.

The composition, structure, spatial and temporal distribution patterns of aquatic insects from Gorgona have been studied since the 1990s, at different scales (Cala, 1990; Vásquez et al., 1996; Zamora et al., 1996; LongoSánchez et al., 2009). Longo-Sánchez and Blanco (2014) described ecological variables structuring the aquatic entomofauna at three different spatial scales. These works used immature stages and a taxonomic resolution at the generic level, but Zúñiga et al. (2014) actualized the systematic knowledge of the aquatic insects from Gorgona working at the species level in Ephemeroptera and Plecoptera; this work also presented new elements for the study of the faunistic relationships of the island with continental mainland.

The aim of the present contribution is to describe two new species of Leptophlebiidae, from the genera Terpides and Thraulodes, to give additional records for four species of the family in the genera Farrodes and Hagenulopsis and to include distributional maps for all these species. This work is part of the larger project "Evaluation of the actual state of the faunistic conservation objects from Gorgona Island: a holistic approximation to the ecological value of the Gorgona National Natural Park" (Giraldo and Valencia, 2012; Giraldo and Diazgranados, 2014).

\section{Material and methods}

Area of study: Climate in the Island is tropical maritime super humid, with mean air temperature around $26^{\circ} \mathrm{C}$, and relative humidity of $90 \%$ saturation. Monthly precipitation varies between 180 and $400 \mathrm{~mm}$ in the drier season (January-March) but from 550 to $750 \mathrm{~mm}$ in the wet season (April-December). The extreme pluviosity, around $6000 \mathrm{~mm}$ in a year, is caused by the annual migration of the Intertropical Convergence Zone.

Immature and adult specimens of Leptophlebiidae were studied; they were collected in the following streams of the oriental sector of the Island: Aeropuerto, Chorro del Cura, Ilú, Iguapoga and Pizarro. Collecting sites correspond to low order streams, $2-5 \mathrm{~m}$ width, depth less than $0.6 \mathrm{~m}$, with good environmental quality and with relatively well preserved forests in the margins and basin (Fig. 1). Immature insects were collected in February (drier season) and June (rainy season) 2011 by using D-net, Surber sampler $\left(0.09 \mathrm{~m}^{2}, 500 \mathrm{~m} \mu\right.$ pore $)$, and direct hand-picking with forceps. Adults were attracted to light-traps located in streams margins (a reflecting screen and white and ultraviolet light emitting diodes (LEDs)), during five field trips between October 2010 and June 2011. In addition, samples from forest trails, traps on 15-20 m tall trees, and 
Malaise traps (2-4 m high) were used. The time of capture with these traps was mainly from 18 to $21 \mathrm{~h}$; except Malaise traps, during $48 \mathrm{~h}$.

Specimens were fixed and preserved in $96 \%$ ethanol. Body parts of nymphs (mouthparts and legs) and imagos (wings, genitalia) and other structures were dissected under $10 \times$ magnification and mounted on microscope slides, using Euparal ${ }^{\circledR}$ or Canada Balsam. The character tarsal claw denticulation is represented as a formula (e.g., $2-3+0$ ) indicating first the number of marginal denticles on the basal half of the claw (in the example varying from two to three) plus the number of apical submarginal denticles, following Domínguez et al. (2006).

Photographs were taken either using a NIKON SMZ-10 stereomicroscope with a NIKON D5000 digital camera or a NIKON SMZ-1500 stereomicroscope or a NIKON ECLIPSE Ni-U90 microscope with a Nikon digital camera NIKON DS-Ri 1 U3 using the software NIS ELEMENTS $\mathrm{Br}$ for analysis of partially focused digital images. Line drawings were done using a camera lucida attached to a microscope.

Maps were done with Geographic Coordinate System: GCS Bogotá, Datum: D Bogotá and the software ESRI ${ }^{\circledR}$ ArcMap 10.0 licence ArcInfo.

Housing institutions: Museo de la Universidad del Valle (MUSENUV), Cali, Colombia, and Instituto de Biodiversidad Neotropical (IBN), Tucumán, Argentina.

\section{Results}

Terpides iguapoga sp. nov. Molineri, Domínguez, Zúñiga (Figs. 2, 3 and 4(A))

Type material: Holotype male imago (parts on slide) from COLOMBIA, Cauca, Guapi, PNN Gorgona: Iguapoga alta creek-Cerro Trinidad trail, N 02 58'27.5”, W 78 $11^{\prime} 0.7^{\prime \prime}, 170 \mathrm{~m}$ asl, 27/ii/2011, light trap. Paratypes: one female imago (parts on slide), same data as holotype; one male subimago, Pizarro creek, Playa Yundigua trail (above intersection), N 02 58'43.7", W 78 10'29", $10 \mathrm{~m}$ asl, 25/ii/2011, light trap, M. del C. Zúñiga, W. Cardona, R.J. Cardozo-Zúñiga cols. (MUSENUV); one female subimago, the same data except Ilu creek, Acueducto trail, N 02 58'3.4", W 78 10'45.2', $20 \mathrm{~m}$ asl, 22/ii/2011, light trap (MUSENUV); one male imago (parts on slide) same data except Chorro del Cura creek, Cerro Trinidad trail (above the village) N 02 58'21.5", W 78 10'43.4", $90 \mathrm{~m}$ asl, 26/ii/2011, light trap (MUSENUV); one nymph, same data, except microhabitat: stream bed stone, 29/vi/2011, C. Cultid, A.M. Chará-Serna (MUSENUV); one male subimago (parts on slide) and one female subimago, same data except Ilu creek trail (water supply-intake), N $02^{\circ} 59^{\prime} 22.7^{\prime \prime}$, W 78 10'06", $75 \mathrm{~m}$ asl, 22/ii/2011, light trap (MUSENUV); one male subimago, same data except Chorro del Cura creek, Cerro Trinidad trail (above the village), N 02 58'21.5”, W 78 10'43.4", $90 \mathrm{~m}$ asl, from 30/vi/2011 to $01 /$ vii/2011, white light LEDs trap, 15-20 $\mathrm{m}$ high, J. Mendivil col. (MUSENUV); one nymph (parts on slides), Pizarro creek,
Playa Yundigua trail (above intersection), $\mathrm{N} 02^{\circ} 58^{\prime} 43.7^{\prime \prime}$, W 78 10'29", $10 \mathrm{~m}$ asl, microhabitat: stream bed stone, 25/ii/2011, M. del C. Zúñiga, W. Cardona, R.J. CardozoZúñiga cols. (MUSENUV).

Diagnosis: Nymph of Terpides iguapoga sp. nov. can be distinguished from other species of the genus by the following combination of characters: (1) labrum with five blunt and rounded denticles on fore marginal indentation (Fig. 3(E)); (2) labial palp: segment I with row of eightnine stout spine-like setae on outer margin, segment II with simple seta on outer margin and three stout spines on inner margin, segment III with eight-ten spine-like setae on inner margin (Fig. 3(D)); (3) fore trochanter and femur with row of strong spine-like setae on inner margin (Fig. 2(A)); (4) fore tarsal claw with a large denticle in the middle, a basal set of two smaller denticles and a distal set of eight-nine even smaller denticles (Fig. 2(B)); (5) gills with blackish tracheae (Figs. 2(D) and 3(B)); (6) posterolateral projections present on terga VI and VIII-IX (Fig. 3(C)); in the adult stage: (1) upper portion of eyes orangeish white (Fig. 5(A) and (B)); (2) forewing membrane hyaline tinged with yellowish around crossveins and marginal intercalary veins (Fig. 5(H) and (J)); (3) genitalia with penes abruptly narrowing on distal third (Fig. 2(E) and $(\mathrm{F}))$.

\section{Description}

Male imago. Length: body, 4.0-5.1 mm, forewings, 4.5-4.7 mm, hind wings, $0.6 \mathrm{~mm}$.

General coloration yellowish with blackish spot on abdomen and brownish marks on wings (Fig. 4(A)). Head whitish, upper portion of eyes orangish white, ventral portion and stalk black. Ocelli white, bordered with black, lateral ocelli twice the size of median one. Antenna yellowish white (Fig. 5(A) and (B)). Thorax: pronotum yellowish white with black paramedian dot and a $\mathrm{V}$-shaped mark encompassing posterior margin; mesonotum yellowish white with margin and sutures orangebrown; metanotum yellowish white with posterior margin blackish (Fig. 5(A) and (B)). Pleura and sterna yellowish white with blackish marks on membranous parts. Legs. Foreleg: coxa and trochanter yellowish orange with dorsal blackish mark on trochanter; rest of leg yellowish translucent with femora and base of tibiae tinged with orange-brown, femora tinged with black longitudinally, interrupted diagonally as in (Fig. 5(F)). Middle and hind leg: coxa and trochanter light orange yellowish, black spot on coxa; femur yellowish white with median black spot and apex orangish; tibia and tarsi yellowish white with base of tibia orangish and with small basal black stripe (Fig. 5(G)). Wings: membrane hyaline tinged with yellowish around crossveins as in Figure 5(H); longitudinal veins yellowish darker on yellowish areas, crossveins grayish brown surrounded with brownish on $\mathrm{C}, \mathrm{Sc}$ and $\mathrm{R}_{1}$ sector. Hind wings with yellowish veins and dark spot at base (Fig. 5(I)). Abdomen: segments I-VII whitish, VIII-X yellowish orange; hind margins of terga I-VIII blackish; anterolateral black spots on terga II-VI (very slightly marked on VII), posterolateral elongated marks on II-VII, decreasing in size and intensity toward rear 


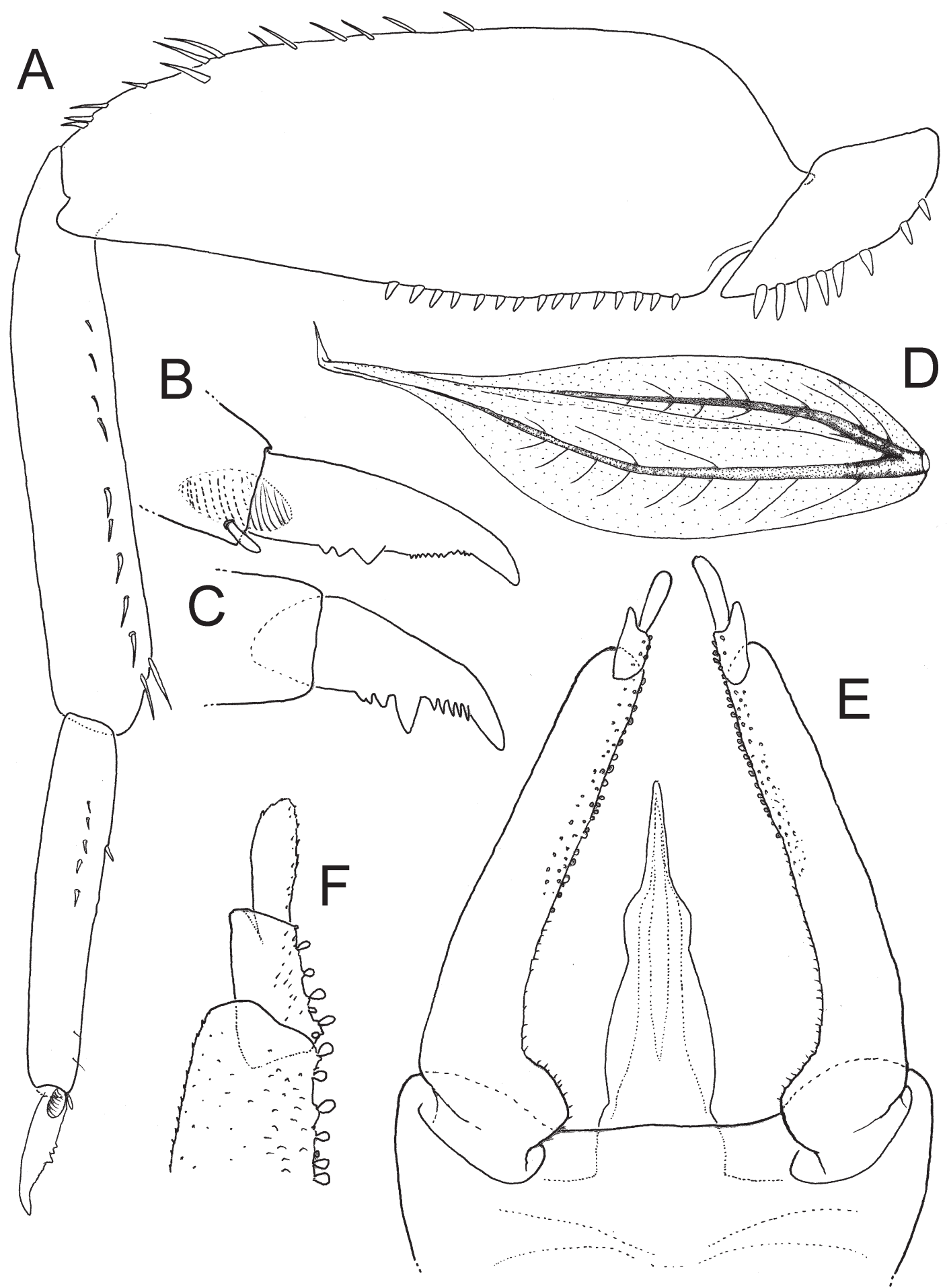

Fig. 2 A-F: Terpides iguapoga sp. nov. Female mature nymph. A: Foreleg, dorsal view; B: Detail of foreclaw; C: Detail of middle claw; D: Abdominal gill I. Male imago. E: Genitalia, ventral view; F: Detail of apex of forceps, ventral view.

segments (Fig. 5(C) and (D)). Sterna I-II with triangular anterolateral black marks, III-VII with sublateral black stripes decreasing in size toward rear segments (Fig. 5(C) and (D)). Genitalia: styliger plate yellowish lighter apically with blackish mark on posterolateral corners; forceps and penis translucent, penis ducts yellowish (Fig. 2(E) and (F)). Caudal filaments yellowish translucent with basal third of each annulus blackish, whitish apical area increasing toward apex of filaments (Fig. 4(A)).

Female imago. Length: body, $4.5 \mathrm{~mm}$, forewings, $4.7-5.3 \mathrm{~mm}$, hind wings, $0.7 \mathrm{~mm}$. Head as in male, eyes black. Thorax as in male except nota yellowish orange. Wings and legs similar to male (Fig. 5(J) and (K)). Abdomen yellowish orange with hind margin of terga 


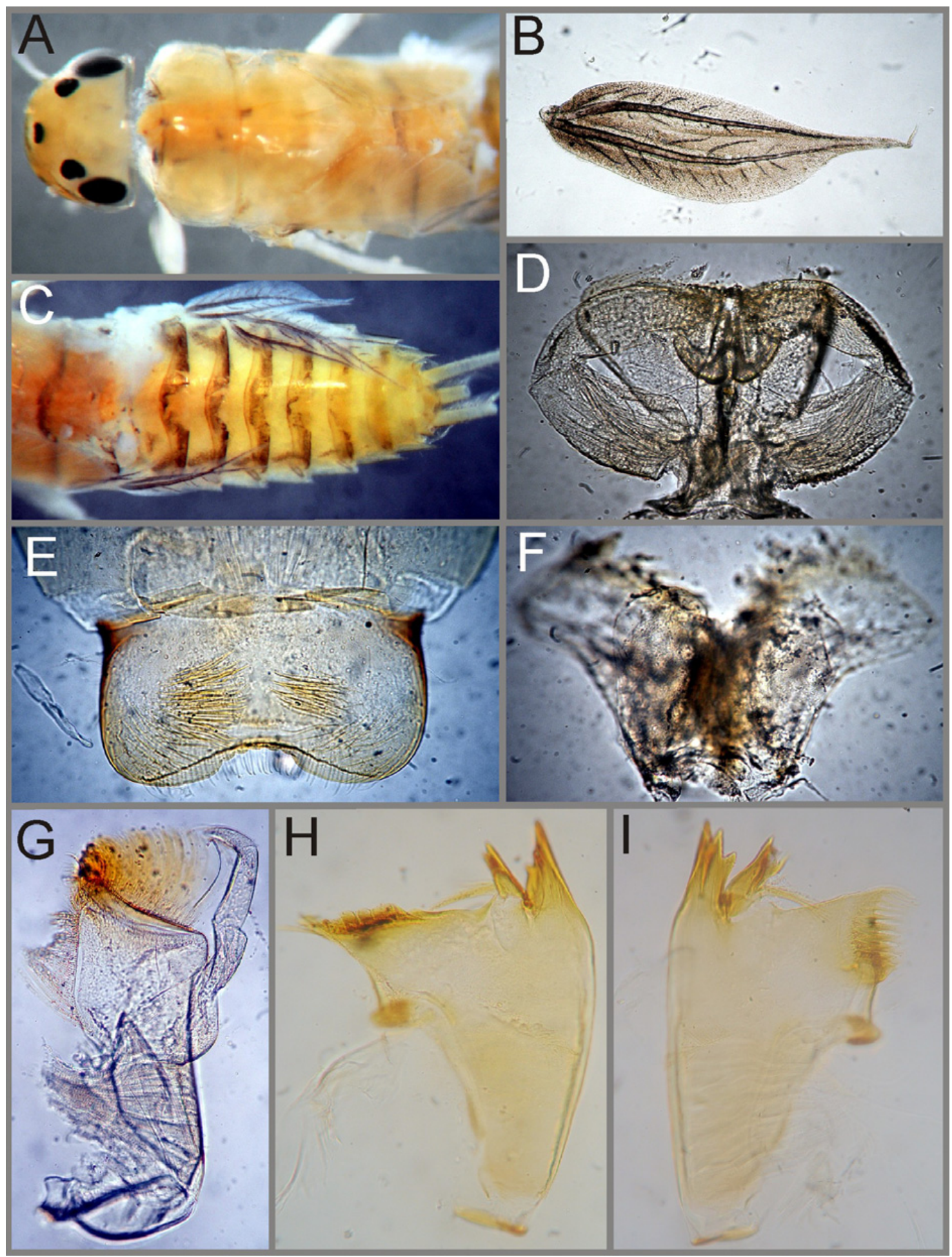

Fig. 3 A-I: Terpides iguapoga sp. nov., female mature nymph. A: Head and thorax, dorsal view; B: Abdominal gill I; C: Abdomen, dorsal view; D: Labium, ventral view; E: Labrum, dorsal view; F: Hypopharynx, ventral view; G: Right maxilla, dorsal view; H: Right mandible, dorsal view; I: Left mandible, dorsal view.

I-VII blackish, and with a blackish $\mathrm{W}$-shaped mark on terga III-VI; terga I-II and VIII-X widely pigmented with black (Fig. 5(E)).

Female nymph (putative). Length: body: $4.2 \mathrm{~mm}$. General color yellowish orange. Head yellowish orange, eyes and ocelli black (Fig. 3(A)). Antennae yellowish white, lighter apically. Mouthparts. Labrum (Fig. 3(E)): maximum length (measured on lateral lobe, not on median emargination) $/$ maximum width $=0.54$; anteromedian emargination with five rounded denticles; distal 


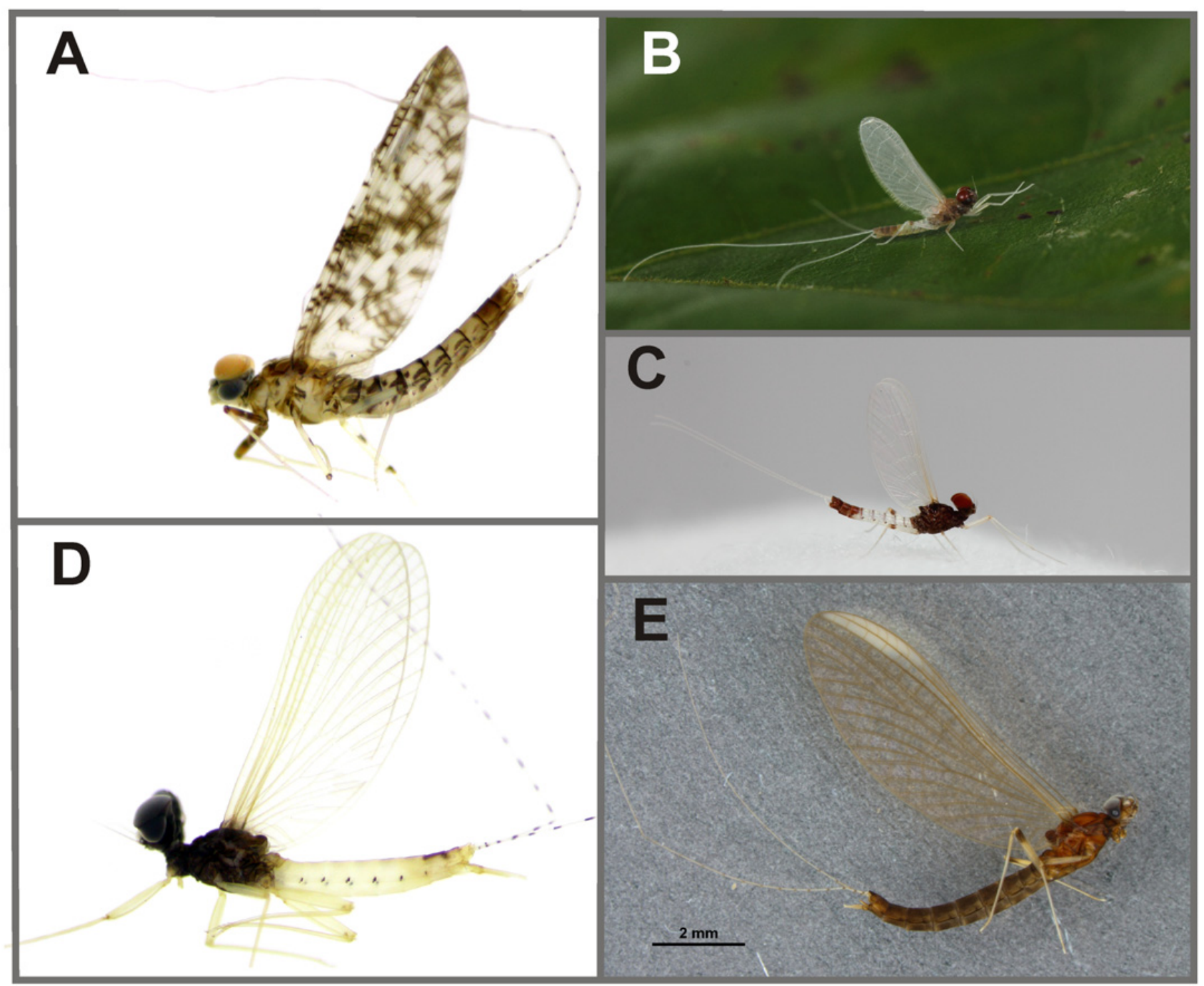

Fig. 4 A-E: Male imago, general view. A: Terpides iguapoga; B: Farrodes roundsi (subimago); C: Farrodes caribbianus; D: Hagenulopsis esmeralda; E: H. zunigae.

margin with a row of fine, simple setae and a submarginal dorsal row of slightly thinner and longer setae, remaining dorsal surface with scattered long simple setae; ventral surface with submedian tuft of long setae directed medially. Left mandible (Fig. 3(I)) with straight outer margin, incisors with three main denticles on inner set and four on outer set; prostheca with a wide and apically denticulated portion and a basal tuft of numerous long bristles. Right mandible (Fig. 3(H)): outer margin straight except broadly curved distally; incisors with two main denticles on inner set and three on outer set; apical inner margin with row of setae, dorsal surface with a tuft of weak setae near central area; prostheca formed by sevennine bristles joined basally in a short stalk. Hypopharynx (Fig. 3(F)): lingua subrectangular with rounded margins and without lateral processes, superlingua laterally projected, inner margin with rows of long curved setae. Maxilla (Fig. 3(G)): inner ventral apex of galea-lacinia with two large setae: one pectinate and one simple long and curved setae, this area dorsally with two smaller pectinate setae; inner lateral margin with row of long, simple setae becoming longer and thinner towards base; palp with strong base (palpifer) and three segments: palp segment II 1.3 length of segment I; palp segment III 0.9 length of segment I. Labium (Fig. 3(D)): palp segment II 0.8 length of segment I; palp segment III 0.6 length of segment I; segment I with long simple setae on inner margin, outer margin with eight-nine stout spine-like setae; segment II with row of four long simple setae on outer margin and three stout spines on inner margin; segment III conical with eight-ten spine-like setae on inner margin, long simple setae on outer margin and with a diagonal row of stronger setae on dorsum; paraglossa laterally rounded and covered with setae on distal 1/3; glossa twisted ventrolaterally, with setae on margins. Thorax. Nota yellowish orange with anterior margin of pronotum blackish, pleura yellowish white with blackish mark dorsally to trochanter II-III, and sterna yellowish orange (Fig. 3(A)). Legs yellowish white with blackish mark on coxa II; fore trochanter with row of eight-ten 


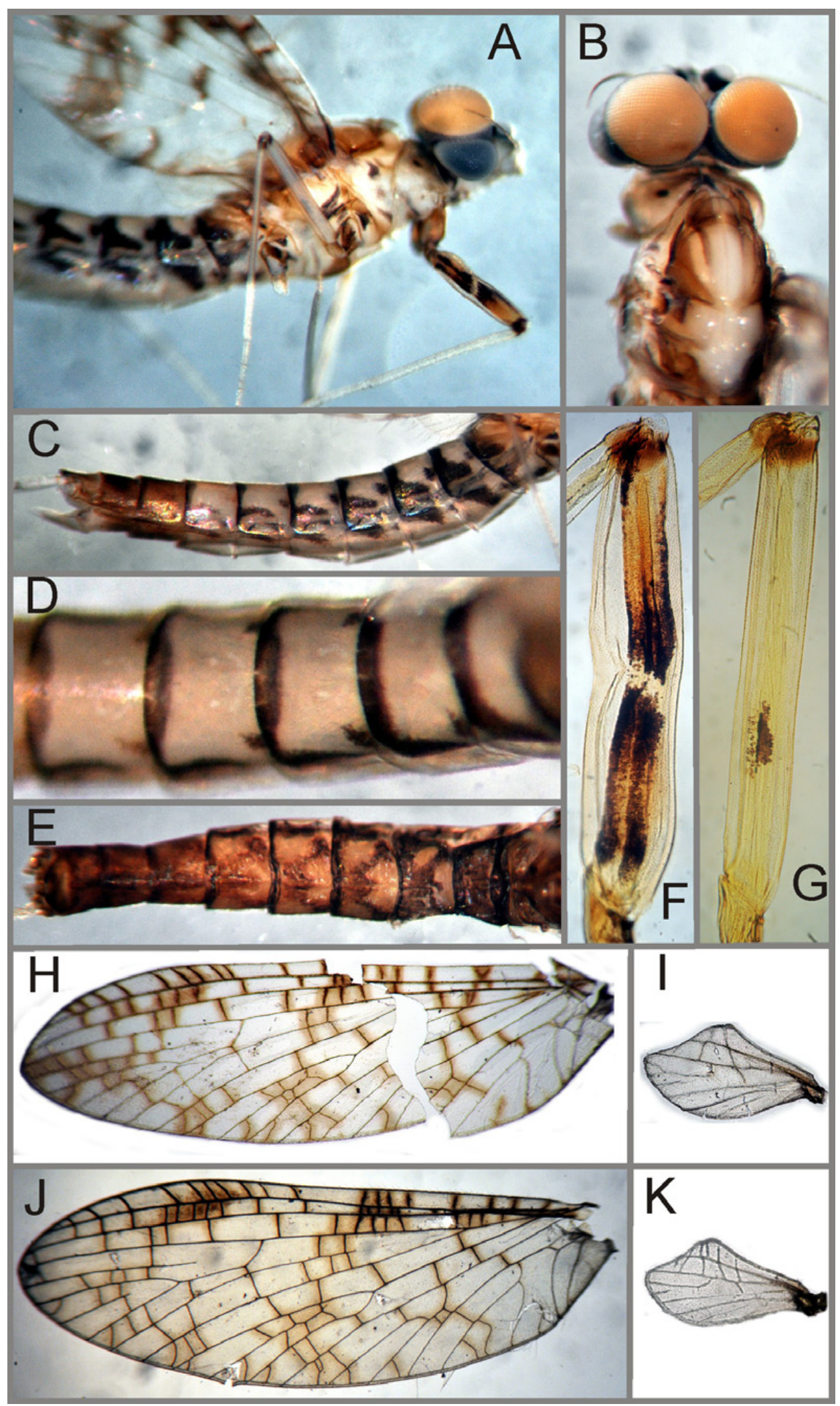

Fig. 5 A-K: Terpides iguapoga sp. nov., adult. A: Head and thorax of male, lateral view; B: Same, dorsal view; C: Male abdomen, lateral view; D: Male abdominal terga I-V; E: Female abdomen, dorsal view; F: Male fore femur (subimago); G: Male hind femur (subimago); H: Male forewing; I: Detail of male hind wing; J: Female forewing; K: Detail of female hind wing. 
large strong spines on inner margin; fore femora with row of 15 stout spines on basal $2 / 3$ of inner margin, and group of weaker spines ventrally and submarginaly; outer margin with 18-20 stout spines (larger than those on inner margin); fore tibiae with a double row of short spine-like setae, and with two longer spines near apex; fore tarsi with two rows of spine-like setae; tarsal claw with a larger denticle in the middle, basal set with three small denticles, distal set with 12 smaller denticles (Fig. 2(A) and (B)). Middle leg similar to foreleg except trochanter with only one spine on inner margin, and femur with 22-25 large spines scattered on dorsum; tibia with row of spines also in outer margin, tarsi only with one row of spines on inner margin; tarsal claw similar to foreclaw except four denticles in basal set and five-six in distal set (Fig. 2(C)). Abdomen yellowish orange, shaded with black along hind margin and sublateral stripe on terga I-VIII, less marked toward rear segments; sternum I with sublateral black spot on posterior margin, sublateral black stripe on sterna I-VII. Hind margins of terga VII-IX with a row of small slender denticles; posterolateral spines present on segments VI and VIII-IX (Fig. 3(C)). Gills: translucent with tracheae grayish black, both lamellae gradually narrowing toward apex, without lateral projections (Fig. 2(D)). Caudal filaments yellowish orange lighter apically.

Etymology: iguapoga, from the name of one of the creeks inhabited by the species.

Discussion. Nymphs of four species of Terpides are known: Terpides diadema Lugo-Ortiz and McCafferty (1996), Terpides jessiae Peters and Harrison (1974), Terpides guyanensis Demoulin (1966) and Terpides sooretama Boldrini et al. (2009). A thorough comparison and a key to the nymphs were presented in Boutonnet et al. (2004), and later Boldrini et al. (2009) added some characters for T. sooretama. T. iguapoga is similar to $T$. jessiae in color pattern of fore femur (dark except pale area at the middle), and is similar to $T$. jessiae and $T$. sooretama in mouthparts and leg setation but differs in the number of denticles on anterolateral emargination of labrum (five in T. iguapoga, six in the others) and in the arrangement of posterolateral abdominal projections (on segments VI and VIII-IX in T. iguapoga, but on III-VI and VIII-IX in the others). T. iguapoga differs from $T$. diadema because the latter species only shows posterolateral projections on abdominal segments VIII-IX, and labial palp segment II has three long bristles on inner margin (vs. three stout spines in T. iguapoga). Finally, T. iguapoga nymphs present abdominal trachea pigmented completely with black, differing from $T$. guyanensis with trachea intercalating pigmented and non-pigmented portions.

The species known in the adult stage are $T$. jessiae, Terpides vinculum (Traver, 1947) and T. sooretama. $T$. iguapoga presents unique male genitalia, because the penis becomes abruptly thin in the distal third. The smoky areas around forewing crossveins are also present in these species, but they are more widely distributed, around and between the veins, in T. iguapoga. T. vinculum is only known from the female adult from Costa Rica, but differs from T. iguapoga in its darker general coloration and in the form of hind wing costal projection (single and rounded in T. vinculum, bilobed in T. iguapoga) and venation (more veins and forks on $\mathrm{M}$ sector in T. vinculum, see Fig. 19 in Traver, 1947).

Roldán (1985), Zúñiga et al. (2004) and Domínguez et al. (2006) mentioned the presence of the genus Terpides in Colombia but Terpides iguapoga is the first species of the genus recorded from this country. Nymphs were collected only from two creeks in the oriental sector, they were found on gravel and pebble, and leaf packs, they were absent from larger stony substrate and sandy patches (Zúñiga et al., 2014). Adults collected along river banks, were widely distributed but scarce (ten specimens), one of them being captured in the forest canopy at a height of 15-20 m (Fig. 6(A)).

Thraulodes insular sp. nov. Domínguez, Molineri, Zúñiga (Figs. 7-9)

Type material: Holotype male imago (MUSENUV) from COLOMBIA, Cauca, Guapi, PNN Gorgona: Iguapoga-alta creek, Cerro Trinidad trail, N 02 58'27.5', W $78^{\circ} 11^{\prime} 0.7^{\prime \prime}, 170 \mathrm{~m}$ asl, 27/ii/2011, light trap. Paratypes: one female imago (MUSENUV) same data as holotype; one male (parts on slide) and one female imagos, Pizarro creek, Playa Yundigua (above intersection) trail, N 02 58'43.7", W 78 10'29", $10 \mathrm{~m}$ asl, 25/ii/2011, light trap, M. del C. Zúñiga, W. Cardona, R.J. Cardozo-Zúñiga cols. (MUSENUV); one reared female subimago and corresponding nymphal cuticle from Chorro del Cura creek, Cerro Trinidad trail (above the village) N 02 58'21.5", $\mathrm{W} 78^{\circ} 10^{\prime} 43.4^{\prime \prime}, 90 \mathrm{~m}$ asl, 26/ii/2011 (MUSENUV); one male and one female imagos from Aeropuerto creek, Playa Blanca-La Azufrada trail (up intersection), N 02 57'29.5', W 78 10'53.1", $25 \mathrm{~m}$ asl, 24/ii/2011, light trap (MUSENUV).

Additional material. COLOMBIA, Cauca, Guapi, PNN Gorgona; three nymphs, Pizarro creek, Playa

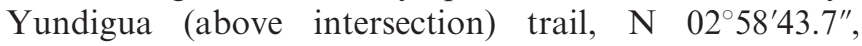
W 78 10'29", $10 \mathrm{~m}$ asl, 25/ii/2011, light trap, M. del C. Zúñiga, W. Cardona, R.J. Cardozo-Zúñiga cols. (two nymphs in MUSENUV, the other in IBN); ten nymphs, same data except Iguapoga-alta creek, Cerro Trinidad trail, $\mathrm{N} 02^{\circ} 58^{\prime} 27.5^{\prime \prime}$, W 78 $11^{\prime} 0.7^{\prime \prime}, 170 \mathrm{~m}$ asl, 27/ii/2011, light trap (five nymph in MUSENUV, the others in IBN). Six nymphs, same data except Ilu creek, Acueducto trail (water supply-intake), $\mathrm{N} 02^{\circ} 58^{\prime} 22.7^{\prime \prime}, \mathrm{W} 78^{\circ} 10^{\prime} 06^{\prime \prime}, 75 \mathrm{~m}$ asl, 22/ii/2011, light trap, M. del C. Zúñiga, W. Cardona, R.J. Cardozo-Zúñiga cols. (MUSENUV); three nymphs (parts of one nymph on slide), same data except Chorro del Cura creek, Cerro Trinidad trail (above the village) $\mathrm{N} 02^{\circ} 58^{\prime} 21.5^{\prime \prime}$, W 78 10'43.4", $90 \mathrm{~m}$ asl, 26/ii/2011, microhabitat: stream bed stone (one nymph in MUSENUV, two nymphs in IBN); one nymph, same data except Aeropuerto creek, Playa Blanca-La Azufrada trail (above intersection), $\mathrm{N} 02^{\circ} 57^{\prime} 29.5^{\prime \prime}$, W $78^{\circ} 10^{\prime} 53.1^{\prime \prime}, 25 \mathrm{~m}$ asl, 24/ii/ 2011, microhabitat: stream bed stone (MUSENUV); two male subimagos, same data except Cerro Trinidad-Y trail, N $02^{\circ} 58^{\prime} 2.3^{\prime \prime}$, W 78 $10^{\prime} 09^{\prime \prime}, 63 \mathrm{~m}$ asl, 27/ii/2011-01/iii/ 2011, LEDs black light trap (15-20 m high), J. Mendivil 

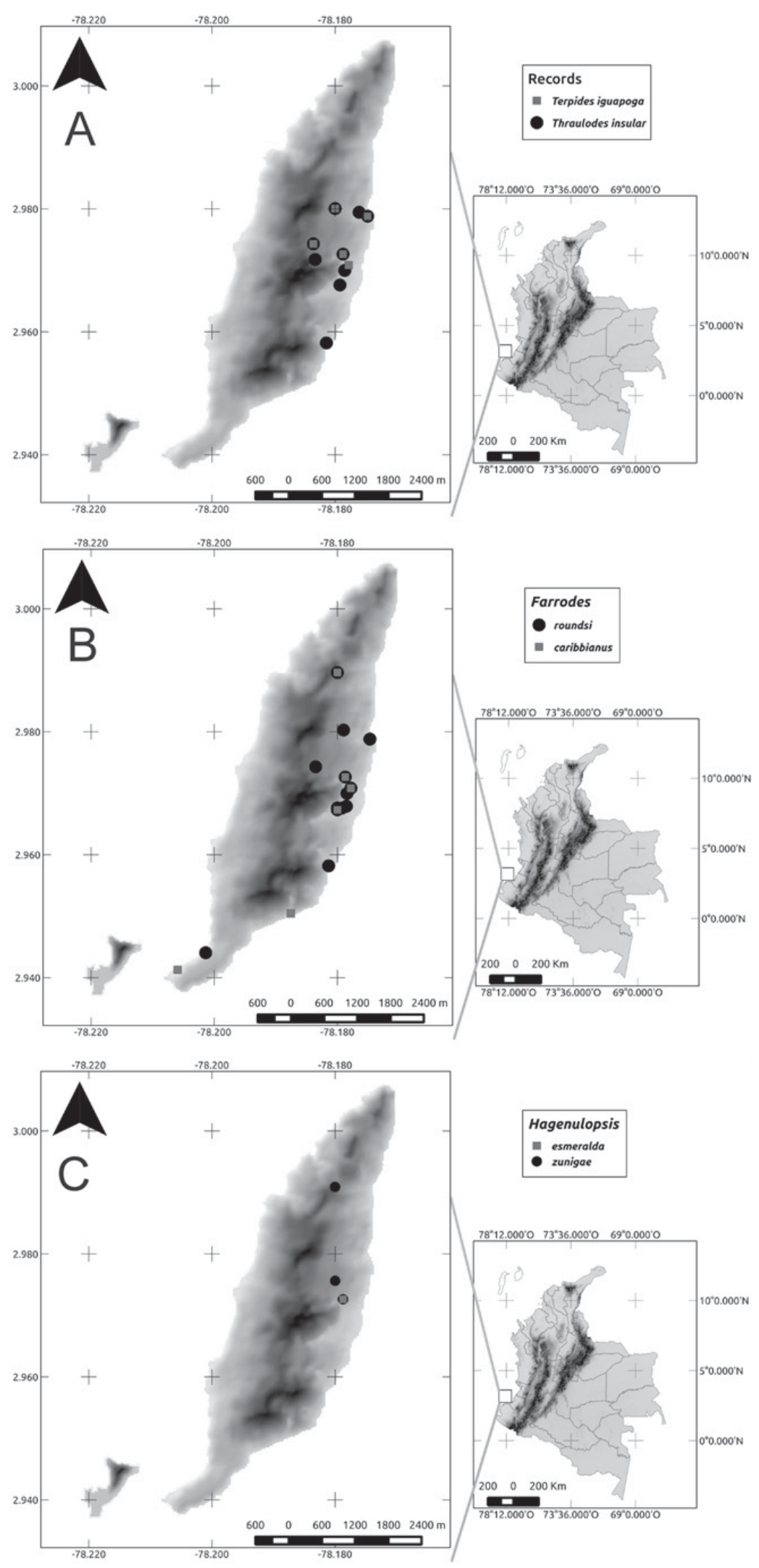

Fig. 6 A-C: Species occurrence in Gorgona Island. A: Terpides iguapoga and Thraulodes insular; B: Farrodes caribbianus and F. roundsi; C: Hagenulopsis esmeralda and H. zunigae. 


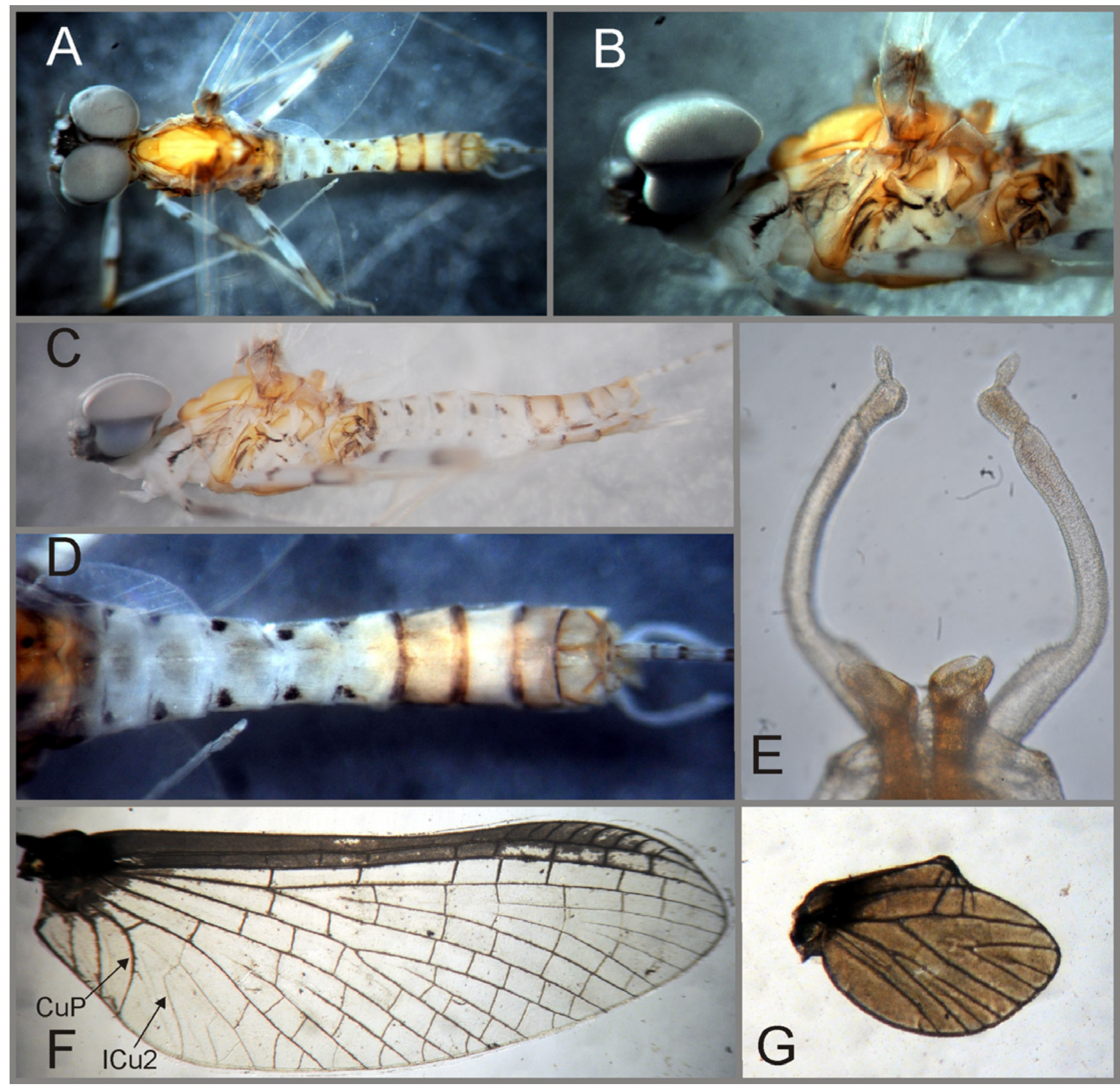

Fig. 7 A-G: Thraulodes insular sp. nov., male imago. A: General dorsal view; B: Head and thorax, lateral view; C: General lateral view; D: Abdomen, dorsal view; E: Genitalia, ventral view; F: Forewing; G: Detail of hind wing.

col. (one subimago in MUSENUV, the other in IBN); one female subimago, same data except La Chonta trail, N 02 58'3.4", W 78 10'45.2", $14 \mathrm{~m}$ asl, 21/x/2010-22/x/ 2010, LEDs white light trap (15-20 m high), F. Sarria, S. Valdés col. (MUSENUV).

Diagnosis: $T$. insular sp. nov. can be separated from the other species of the genus by the following combination of characters. In the nymph: (1) abdominal gills with narrow lamellae with only the main trachea present (Fig. 8(E)); (2) tarsal claw with six-nine denticles increasing in size toward apex; abdomen with anterolateral black spots in terga as in Fig. 9(A); (3) femora with black streak along apical portion of anterior margin (Fig. 9(B)-(D)). In the imago: (1) forewing costal area basal to bulla without crossveins (Fig. 7(F)); (2) costal and subcostal zones of forewing whitish-translucent (Fig. 7(F)); (3) a spot and a band on femora (Fig. 7(A)); (4) terga II-VI translucent white with anterolateral black spot, terga VII-X darker (Figs. 7(A)-(D)); (5) posterior margin of subgenital plate triangular (Figs. 7(E) and 8(A)); (6) penes spines short and robust (similar in length to the apical width of penes) (Fig. 8(B)-(D)), apicolateral area forming an "ear"; weak lateral pouch present; recurved fold absent. 

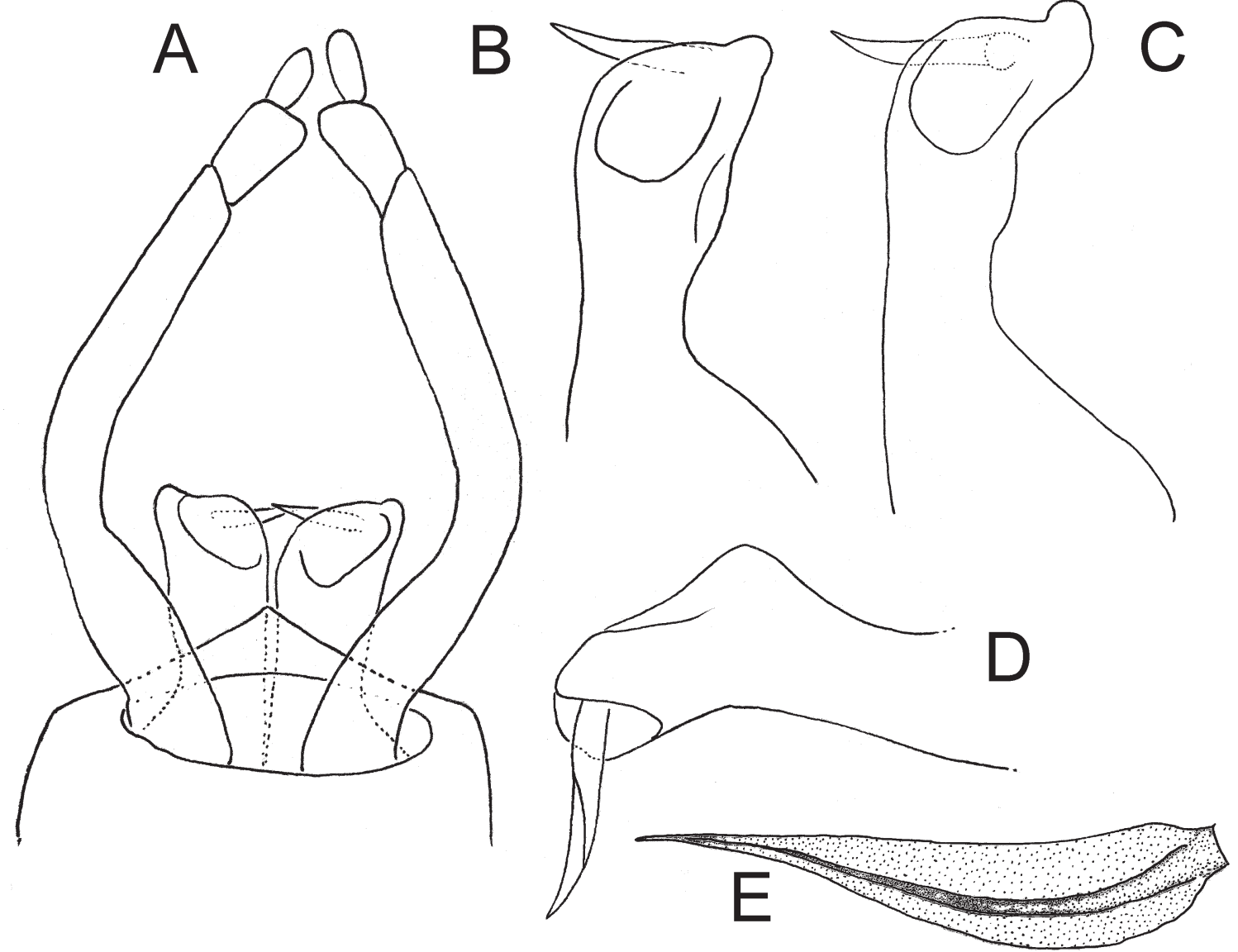

Fig. 8 A-E: Thraulodes insular sp. nov. Male imago. A: Genitalia, ventral view; B, C: Detail of penes, ventral view; D: detail of penes, lateral view. Nymph. E: Abdominal gill IV.

\section{Description}

Male imago. Length: body, $5.8-6.5 \mathrm{~mm}$; forewings, $5.9 \mathrm{~mm}$; hind wings, $1.0 \mathrm{~mm}$. General coloration: yellowish with first abdominal segments translucent white (Fig. 7(A)-(D)). Head: grayish white, anterior margin yellowish. Eyes: upper portion grayish, meeting dorsally; ventral portion blackish (Fig. 7(B)). Ocelli whitish, ringed with black basally; lateral ocelli 2 times the width of the median one. Antennae: scape and pedicel yellowish, scape ringed with black at base, flagellum yellowish white. Thorax: pronotum yellowish white with paramedial brown lines, mesonotum yellowish with sutures and apex of mesoscutellum darker, metanotum yellowish tinged with black (Fig. 7(B)). Pleurae: propleura yellowish white with a black stripe, meso- and metapleura yellowish tinged with black, membranous parts whitish. Sterna: prosternum whitish, meso- and metasternum yellowish, with basisternum lighter. Legs yellowish white with apical third of femora yellowish brown tinged with black and medial black spot on femora, black ring on apex of tibiae, tarsi grayish, apical tarsal segment darker, claws grayish (Fig. 7(A)). Wings: wing membrane hyaline with yellowish veins, lighter toward anal margin, basal brownish spot at base. Forewing without crossveins basal to bullae in costal area, nine-ten distal to bullae; costal and subcostal zones whitish-translucent; veins $\mathrm{ICu}_{2}$ and $\mathrm{CuP}$ not joined basally (Fig. 7(F)). Hind wing (Fig. 7(G)) with eight crossveins. Abdomen: tergum I almost completely blackish brown; terga II-VI translucent white, with central area light yellowish brown and anterolateral black spot; terga VII-X yellowish white with lateral and anterior margin of VII-IX blackish; sterna I-VI translucent white with blackish spiracles, sterna VII-IX yellowish white with posterolateral corners of VII-VIII tinged with black, margins of VIII-IX brownish (Figs. 7(C) and (D)). Genitalia (Figs. 7(E) and 8(A)-(D)): styliger plate and forceps white, penes yellowish, spine darker; maximum width of segment II of forceps 1.5 times the subapical width of segment III. Penes orangish to brownish, apicolateral area forming an "ear"; weak lateral pouch present; recurved fold absent; spine short and robust (similar in length to the apical width of penes). Caudal filaments whitish shaded in a repeated pattern: first annulus white, second blackish, third and fourth grayish.

Female imago. Length: body, 5.6-6.1 mm; fore wings, $6.0-6.2 \mathrm{~mm}$; hind wings, $0.8-0.9 \mathrm{~mm}$. General coloration as male except abdominal segments yellowish white. Head grayish black with anterior margin yellowish white, eyes black, remainder as in male. Thorax, legs and wings as in male. Abdomen as in male, except background color 


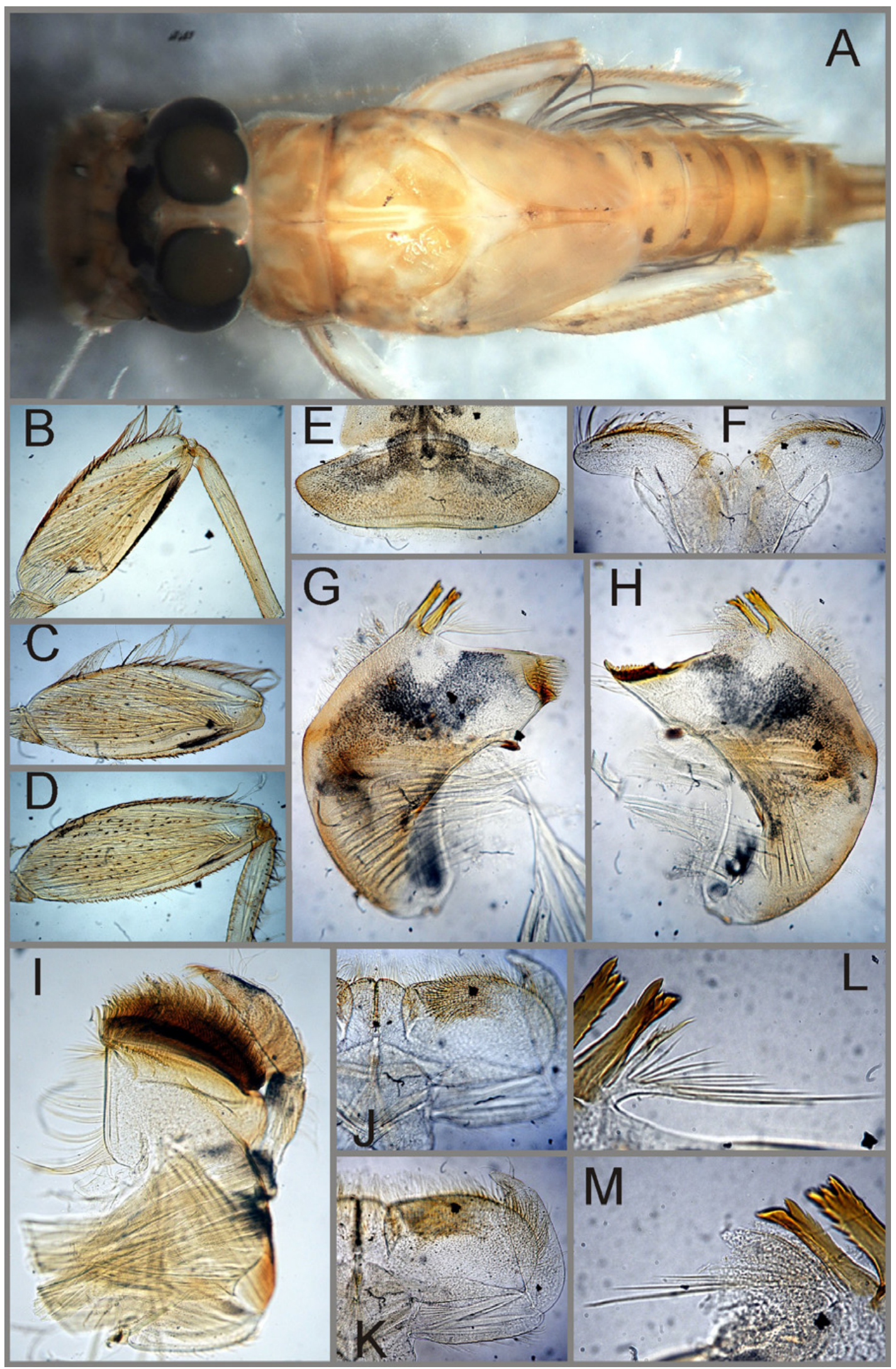

Fig. 9 A-M: Thraulodes insular sp. nov., mature nymph. A: General dorsal view of male; B: Fore femur and tibia, dorsal view; C: Middle femur, dorsal view; D: Hind femur and tibia, dorsal view; E: Labrum, dorsal view; F: Hypopharynx, ventral view; G: Left mandible, dorsal view; H: Right mandible, dorsal view; I: Right maxilla, dorsal view; J: Labium, dorsal view; K: Labium, ventral view; L: Detail of left prostheca; M: Detail of right prostheca. 
yellowish, except segment VIII whitish; sterna II-VI with anterolateral margins blackish.

Nymph. Length of male: body, $5.2-5.5 \mathrm{~mm}$; caudal filaments, $6.5-8.0 \mathrm{~mm}$. Length of female: body, $6.0 \mathrm{~mm}$; caudal filaments, $8.0 \mathrm{~mm}$. General color yellowish brown. Head yellowish brown with V-shaped black mark between eyes, more marked on female; ocelli C-shaped, with black inner part, lens whitish; dorsal portion of male eyes reddish brown, ventral portion blackish, female eyes blackish (Fig. 9(A). Mouthparts yellowish except margins of clypeus, base of labrum, mandibles and maxillae as in (Fig. 9(E)-(L)). Thorax. Nota yellowish with central pale marks as in Figure 9(A); pleura yellowish with membranous parts tinged black; sterna whitish. Legs. Fore femur with small transverse subbasal black mark, distal half of fore margin blackish (Fig. 9(B)); middle and hind femora only with distal half of fore margin blackish but lighter; remainder of legs yellowish white; tarsal claw with six-nine denticles increasing in size toward apex. Abdomen. Tergum I-VI with anterolateral dark spot, tergum I also with posterior margin tinged with black; lateral third of anterior margin of VII-IX blackish, posterior margin of IX also blackish. Sterna yellowish white, central area slightly darker (Fig. 9(A)). Gills narrow, plate-like, gradually narrowing toward apex, main trachea unbranched and blackish, lamella grayish (Fig. 8(E)). Caudal filaments yellowish with even spines on posterior margin of each annulus.

Etymology: the name refers to the insular nature of the distributional area of this species.

\section{Discussion}

In spite of Thraulodes being one of the most diverse and abundant genera of the Americas, this constitutes the fourth species recorded from Colombia; this is surely due to the lack of taxonomic research on this genus in the region (Domínguez et al., 2013; Zúñiga et al., 2014). The three species previously recorded from the country are Thraulodes colombiae (Walker, 1853), Thraulodes laetus (Eaton, 1883), and Thraulodes papilionis Traver and Edmunds (1967). T. colombiae only known from the female adult presents the hind wing costal projection located in the distal third of the anterior margin, T. insular (as in all other females of the genus) presents a subbasal costal projection (Fig. $7(\mathrm{G})$ ). T. laetus, the type species of the genus and known from male adult only, differs from our new species in its posteriorly rounded styliger plate and thinner peneal spines. Finally, T. papilionis, also known only from male adults, can be easily separated from $T$. insular, by its long and slender penes. Two species of Thraulodes are known from Ecuador, a region that shares some species with Gorgona Island, but they are different from the new species described here: Thraulodes osiris Traver and Edmunds (1967), shows a small rounded projection on the apex of the styliger plate, and Thraulodes quevedoensis Flowers (2009) presents male abdominal terga VI-X brownish (in T. insular VII-X are brownish).
The most updated key is in Domínguez et al. (2006) for the South American species of Thraulodes, but there is a more recent one for the Brazilian species (Lima et al., 2013; Souto et al., 2014). In both, T. insular keys to Thraulodes cochunaensis Domínguez (1987), but this species shows a posterior margin of styliger plate strongly projected and slender penes than in $T$. insular.

The nymphs of very few species of the genus are known, those of $T$. insular are similar to $T$. cochunaensis and $T$. quevedoensis in the shape of abdominal gills (with narrow lamellae), but can be separated from them by the presence of a black streak along distal portion of anterior margin of femora (Fig. 9(B)-(D)).

Thraulodes is the second most abundant Leptophlebiid genus in the Island, being represented only by $T$. insular $\mathrm{sp}$. nov., is widely distributed in the streams of Gorgona (Fig. 6(A)). Nymphs occupy mainly rocky substrates, but they were absent from sand. Adults were attracted to light traps (white and UV), from the ground to a height of 15-20 m.

Farrodes caribbianus (Traver) (Fig. 4(C))

Thraulus caribbianus Traver, 1943: 79 (male, female); Traver, 1960.

Farrodes caribbianus Domínguez, 1999:159 (nymph).

Material examined: COLOMBIA, Cauca, Guapi, PNN Gorgona: ten male imagos, Ilu creek, Acueducto trail, $\mathrm{N} 02^{\circ} 58^{\prime} 3.4^{\prime \prime} \mathrm{W} 78^{\circ} 10^{\prime} 45.2^{\prime \prime}, 20 \mathrm{~m}$ asl, 30/vi/2011, light trap, C. Cultid, A.M. Chará-Serna cols. (five nymphs in MUSENUV, the other in IBN); five male imagos, same data except Chorro del Cura creek,Cerro Trinidad traildown zone, N $02^{\circ} 58^{\prime} 15^{\prime \prime}$, W $78^{\circ} 10^{\prime} 40.1^{\prime \prime}, 40 \mathrm{~m}$ asl, 29/vi/ 2011, light trap (two imagos in MUSENUV, the other in IBN); four male imagos, three female imagos, same data except Chorro del Cura creek, Cerro Trinidad trail (above the village) $\mathrm{N} 02^{\circ} 58^{\prime} 21.5^{\prime \prime}$, W $78^{\circ} 10^{\prime} 43.4^{\prime \prime}, 90 \mathrm{~m}$ asl, 26/ii/ 2011, light trap, M. del C. Zúñiga, W. Cardona, R.J. Cardozo-Zúñiga cols. (MUSENUV); one nymph, same data except microhabitat: stream bed stone (MUSENUV); two male imagos, same data except Playa Palmera (near guesthouse) (on vegetation), $\mathrm{N} 02^{\circ} 56^{\prime} 28.6^{\prime \prime}$, W 78 $12^{\prime} 21.4^{\prime \prime}$, $28 \mathrm{~m}$ asl, 22/ii/2011, J. Mendivil col. (MUSENUV); one male imago, same data except Trinidad Cerro-Y trail, $\mathrm{N} 02^{\circ} 58^{\prime} 2.3^{\prime \prime}$, W 78 $10^{\prime} 09^{\prime \prime}, 63 \mathrm{~m}$ asl, from $27 / \mathrm{ii} / 2011-01 /$ iii/2011, black light LEDs trap, on canopy (15-20 m high), J. Mendivil col. (MUSENUV); two male imagos, same data except Playa Blanca-La Azufrada trail (near creek), $\mathrm{N} 02^{\circ} 57^{\prime} 1.6^{\prime \prime}$, W $78^{\circ} 11^{\prime} 15.2^{\prime \prime}, 13 \mathrm{~m}$ asl, from $19 / \mathrm{x} / 2010$ to 22/x/2010, Malaise trap on vegetation (2-4 m high), D. Torres (MUSENUV); four male subimagos, same data except La Chonta trail, N 02 58'3.4", W 78 10'45.2", 14 m asl, from $21 / \mathrm{x} / 2010$ to $22 / \mathrm{x} / 2010$, white light LEDs trap (15-20 m high), F. Sarria, S. Valdés col. (MUSENUV).

Discussion. This species, known from all the stages has been originally recorded from the Antilles, but later from Costa Rica, Panamá, Venezuela and Colombia (Domínguez, 1999; Domínguez et al., 2006) (Fig. 4(C)). It was recently recorded from Gorgona NNP (Zúñiga et al., 2014), and we here provide new localities for the species (Fig. 6(B)). 
Farrodes is the most frequent Leptophlebiidae collected in the Island, with two sympatric species (F. caribbianus and $F$. roundsi). F. caribbianus showed lower abundances during the collecting period (8\%) (Zúñiga et al., 2014).

Farrodes roundsi (Traver) (Fig. 4(B))

Thraulus roundsi Traver, 1943: 153 (male, female); Traver, 1960: 73.

Farrodes roundsi Domínguez, 1999: 161, Domínguez and Zúñiga, 2009: 74 (nymph).

Material examined: COLOMBIA, Cauca, Guapi, PNN Gorgona, ten male imagos, Ilu creek, Acueducto trail (water supply-intake), N 02 58'22.7", W 78 $10^{\prime} 06^{\prime \prime}, 75 \mathrm{~m}$ asl, 22/ii/2011, light trap, M. del C. Zúñiga, W. Cardona, R.J. Cardozo-Zúñiga cols. (five in MUSENUV, five in IBN); four nymphs, same data (MUSENUV); one male imago, same data except, N $02^{\circ} 58^{\prime} 3.4^{\prime \prime}$, W 78 10'45.2", $20 \mathrm{~m}$ asl, 30/vi/2011, light trap, C. Cultid, A.M. CharáSerna cols. (MUSENUV); eight male imagos, Iguapoga creek, La Chonta trail (cross), N 02 58'11.9", W 78 $10^{\prime} 42.4^{\prime \prime}, 30 \mathrm{~m}$ asl, 23/ii/2011, light trap, M. del C. Zúñiga, W. Cardona, R.J. Cardozo-Zúñiga cols. (four in MUSENUV, four in IBN); two nymphs, same data (MUSENUV); four male imagos, same data except Iguapoga alta, Cerro Trinidad trail, N 02 58'11.9", W 78 10'42.4", $170 \mathrm{~m}$ asl, 27/ii/2011, light trap, M. del C. Zúñiga, W. Cardona, R.J. Cardozo-Zúñiga cols. (two in MUSENUV, two in IBN); two nymphs, same data (MUSENUV); one male imago, same data except Aeropuerto creek, Playa Blanca-La Azufrada trail, $\mathrm{N} \mathrm{02}{ }^{\circ} 57^{\prime} 29.5^{\prime \prime}$, W 78 $10^{\prime} 53.1^{\prime \prime}, 25 \mathrm{~m}$ asl, 24/ii/2011, light trap, M. del C. Zúñiga, W. Cardona, R.J. CardozoZúñiga cols. (MUSENUV); four nymphs, same data (MUSENUV); six male imagos, same data except Pizarro creek, Playa Yundigua, N 02 58'43.7", W 78 $10^{\prime} 29^{\prime \prime}, 10 \mathrm{~m}$ asl, 24/ii/2011, light trap, M. del C. Zúñiga, W. Cardona, R.J. Cardozo-Zúñiga cols. (IBN); seven male imagos, the same information except N $02^{\circ} 58^{\prime} 46^{\prime \prime}$, W $78^{\circ} 10^{\prime} 34^{\prime \prime}, 40 \mathrm{~m}$ asl, 01/vii/2011, light trap, C. Cultid, A.M. Chará-Serna cols. (MUSENUV); two nymphs, same data except 24/ii/ 2011 (MUSENUV); eight male imagos, same data except Chorro del Cura creek, Cerro Trinidad trail, $\mathrm{N} \mathrm{02} 2^{\circ} 58^{\prime} 21.5^{\prime \prime}$, W 78 $10^{\prime} 43.4^{\prime \prime}, 90 \mathrm{~m}$ asl, 28/ii/2011, light trap, M. del C. Zúñiga, W. Cardona, R.J. Cardozo-Zúñiga cols. (four in MUSENUV, four in IBN); four nymphs, same data except 26/ii/2011 (MUSENUV); four males subimagos, same data except 27/v/2011, G. Zabala, H. Calero cols. (MUSENUV); two male imagos, same data except N $02^{\circ} 58^{\prime} 15^{\prime \prime}$, W $78^{\circ} 10^{\prime} 40.1^{\prime \prime}, 40 \mathrm{~m}$ asl, 29/vi/ 2011, light trap, C. Cultid, A.M. Chará-Serna cols. (MUSENUV); two male imagos, same data except Playa Palmera (near guesthouse), N $02^{\circ} 56^{\prime} 38.6^{\prime \prime}$, W $78^{\circ} 12^{\prime} 05^{\prime \prime}$, $44 \mathrm{~m}$ asl, 24/ii/2011, LEDs white light trap (15-20 m hight), J. Mendivil col. (MUSENUV); two male imagos, same data except Cerro Trinidad-Y trail, N 02 58'2.3", W 78 10'09", $63 \mathrm{~m}$ asl, 27/ii/2011-01/iii/2011, LEDs black light trap (15-20 m hight), J. Mendivil col. (IBN); one male imago, same data except La Chonta trail, N 02 58'3.4", W 78 10'45.2", $14 \mathrm{~m}$ asl, 18/x/2010-19/x/ 2010, LEDs white light trap (15-20 m hight), F. Sarria,
J. Mendivil col. (MUSENUV); one male imago, same data except Playa Yundigua trail, N 02 58'4.8”, W 78 10'5.3", $41 \mathrm{~m}$ asl, 20/x/2010-22/x/2010, Malaise trap on vegetation (2-4 m high), D. Torres col. (MUSENUV).

Discussion: This species is known from Panamá, Costa Rica and Colombia, where it is known mainly from the occidental Andean area; the record from Gorgona extended its geographic range towards the Pacific of Colombia (Domínguez et al., 2006; Zúñiga et al., 2014). Its distribution is similar to that of its sister species (F. caribbianus) in northern South America (Domínguez, 1999; Domínguez and Zúñiga, 2009). But in contrast to F. caribbianus only captured in two creeks of the oriental sector in Gorgona), F. roundsi had a wide distribution along all the studied streams (Fig. 6(B)). Adults were dominant in the light traps $(92 \%)$ from the ground level to the canopy traps at 15-20 m (Zúñiga et al., 2014). The capture of many specimens of both sexes in the different collecting dates suggests a rather constant emergence through the year. Nuptial flights were not observed. In Colombia both species are found in low order streams, with good water quality, in the regions of Chocó, occidental Andes and pacific insular area (Domínguez and Zúñiga, 2009; Zúñiga et al., 2014).

Hagenulopsis esmeralda Domínguez, Molineri \& Bersoza (Fig. 4(D))

Hagenuulopsis esmeralda Domínguez et al., 2009: 40-41.

Examined material. COLOMBIA, Cauca, Guapi, PNN Gorgona, one male imago, Chorro del Cura creek, Cerro Trinidad trail (above the village) N 02 58'21.5', W 78 10'43.4", 90 m asl, 27/v/2011, light trap, G. Zabala, H. Calero (MUSENUV).

Discussion. Adults of Hagenulopsis were poorly represented (ten specimens), and only one of them (a male imago) pertains to the species H. esmeralda. This male was attracted to a light trap near riparian vegetation of an oriental sector stream (Figs. 4(D) and 6(C)). This species was previously known from the type material from the Chocó at NW Ecuador, from larger lotic systems at low elevation known as "esteros", nymphs are still unknown (Domínguez et al., 2009).

Hagenulopsis zunigae Domínguez, Molineri \& Mariano (Fig. 4(E))

Hageulopsis zunigae Domínguez et al., 2009: 41-43.

Material examined. COLOMBIA, Cauca, Guapi, PNN Gorgona, one male, two female imagos, Chorro del Cura creek, Cerro Trinidad trail (above the village), $\mathrm{N} 02^{\circ} 58^{\prime} 21.5^{\prime \prime}, \mathrm{W} 78^{\circ} 10^{\prime} 43.4^{\prime \prime}, 90 \mathrm{~m}$ asl, 27/v/2011, light trap, G. Zabala. H. Calero (MUSENUV); one male imago, same data except Playa Yundigua trail, N 02 58'43.7", W $78^{\circ} 10^{\prime} 29^{\prime \prime}, 10 \mathrm{~m}$ asl, from $20 / \mathrm{x} / 2010$ to $22 / \mathrm{x} / 2010$, Malaise trap on vegetation $(2-4 \mathrm{~m}$ high). D. Torres (IBN); one male imago, the same information except Playa Blanca-La Azufrada trail (near creek), N 02 58'21.5", W 78 10'43.4", $13 \mathrm{~m}$ asl, from $19 / \mathrm{x} / 2011$ to $22 / \mathrm{x} / 2011$, Malaise trap on vegetation (2-4 m hight), D. Torres (MUSENUV).

Discussion: This species, here recorded from Gorgona (Figs. 4(E) and 6(C)), was previously known only from the 
type material collected in mountainous protected areas from the Eastern and Western Andes from Colombia (Domínguez et al., 2009; Zúñiga et al., 2014). Nymphs of this genus could not be associated with the adults found in Gorgona, they inhabited all the streams, but at a low abundance.

Acknowledgements. We are indebted to Prof. Alan Giraldo as general director of the research project "Evaluation of the actual state of the faunistic conservation objects from Gorgona Island: an holistic approximation to the ecological value of the Gorgona National Natural Park"; to Universidad del Valle, Fondo para la Acción Ambiental y la Niñez and Conservación Internacional for logistic and monetary support; to the technicians and administrative officials at PNN Gorgona; to Grupo de Investigaciones Entomológicas de la Universidad del Valle and specially to Prof. Ranulfo González, Ricardo CardozoZúñiga, J. Mendivil, Carlos Cultid, Ana Marcela Chará-Serna, Diana Torres, Gustavo Zabala, Stephany Valdés and Fabio Sarria, for their help in the field. Thanks to Cristian Román for the elaboration of maps, and to Francisco López, Diana Torres, Julián Mendivil, Cristhian Salas and Felipe Ortega (Laboratorio de Imágenes de la Universidad del Valle) for photographs. Photographs of the streams are by Diana Torres. Photographs 8A and $\mathrm{D}$ are by Julián MendivilCristhian Salas, 8B and C by Francisco López, 8E by Felipe Ortega from Laboratorio de Imágenes Univalle. Thanks to Frederico Salles for discussion about the new species of Terpides. This work benefited from collecting permits PIBD DTSO O11-10 from Unidad Administrativa Especial del Sistema de Parques Nacionales Naturales de Colombia (UAESPNN).

\section{References}

Blanco J.F., 2009. Características físico-químicas de las quebradas del Parque Nacional Natural Gorgona, Pacífico colombiano. Actual Biol., 31, 23-140.

Boldrini R., Salles F.F. and Cabette H.R., 2009. Contribution to the taxonomy of the Terpides lineage (Ephemeroptera: Leptophlebiidae). Ann. Limnol. - Int. J. Lim., 45, 219-229.

Boutonnet J., Thomas A. and Lala G., 2004. Macroinvertebrates of brooks and rivers of Martinique II. The family Leptophlebiidae: systematics, biogeography and ecological distribution [Ephemeroptera]. Ephemera, 4, 81-112.

Cala P., 1990. Biodiversidad en aguas dulces de la isla. In: Aguirre J. and Rangel O. (eds.), Biota y ecosistemas de Gorgona, Fondo FEN, Bogotá, Colombia, 261-274.

Domínguez E., 1987. El género Thraulodes (Ephemeroptera: Leptophlebiidae) en la República Argentina. Acta Zool. Lill., $39,47-65$.

Domínguez E., 1999. Systematic cladistic and biogeography of the American genus Farrodes (Ephemeroptera, Leptophlebiidae, Atalophlebiinae). Zool. J. Linn. Soc. Lond., 126, 155-189.

Domínguez E. and Zúñiga M. del C., 2009. First description of the nymph of Farrodes roundsi (Traver) (Ephemeroptera: Leptophlebiidae, Atalophlebiinae) with comments on its phylogenetic relationships. Aquat. Insects, 31(Suppl. 1), 73-81.
Domínguez E., Molineri C., Pescador M.L., Hubbard M.D. and Nieto, C., 2006. Ephemeroptera of South America. In: Adis J., Arias J.R., Rueda-Delgado G. and Wantzen K.M. (eds.), Aquatic Biodiversty in Latin America (ABLA), Vol. 2, Pensoft, Moscow, 644 p.

Domínguez E., Molineri C. and Mariano R., 2009. Revision of the South America species of Hagenulopsis Ulmer and Askola Peters (Ephemeroptera: Leptophlebiidae) with description of six new species. Zootaxa, 2142, 29-44.

Domínguez E., Molineri C., Nieto C., Hubbard M.D., Pescador M. and Zúñiga M.delC., 2013. Checklist of South American species of Ephemeroptera. Available online at: http//fada. biodiversity.be/group/show/35.

Eaton A.E., 1883. A revisional monograph of recent Ephemeridae or mayflies. Trans. Linn. Soc. London Zool., 3, 1-352.

Flowers R.W., 2009. A new species of Thraulodes (Ephemeroptera: Leptophlebiidae, Atalophlebiinae) from a highly altered river in western Ecuador. Zootaxa, 2052, 55-61.

Giraldo A., 2012. Geomorfología e hidroclimatología de isla Gorgona. In: Giraldo A. and Valencia B. (eds.), Isla Gorgona, paraiso de biodiversidad y ciencia. Programa Editorial Universidad del Valle, Colección Ciencias Naturales y Exactas, Santiago de Cali, Colombia, 17-23.

Giraldo A. and Valencia V. (Compiladores), 2012. Isla Gorgona. Paraiso de biodiversidad y ciencia. Programa Editorial de la Universidad del Valle, Colección Ciencias Naturales y Exactas, Santiago de Cali, 221 p.

Giraldo A. and Diazgranados M.C. (Editores Científicos), 2014. Investigaciones en el Parque Natural Nacional Gorgona, Colombia. Rev. Biol. Trop., 62(Suppl. 1), 458.

Giraldo A., Diazgranados M.C. and Gutiérrez-Landázuri C.F., 2014. Isla Gorgona, enclave estratégico para los esfuerzos de conservación en el Pacífico Oriental Tropical. Rev. Biol. Trop., 62(Suppl. 1), 1-12.

Lima L.R.C., Mariano R. and Pinheiro U., 2013. New species for Thraulodes Ulmer, 1920 (Ephemeroptera: Leptophlebiidae: Atalophlebiinae) and the first key to adults from Brazil. Zootaxa, 3709(3), 230-242.

Longo-Sánchez M. and Blanco J.F., 2014. Patterns at multi-spacial scales on tropical island stream insect assemblages (Gorgona Island Natural National Park, Colombia, Tropical Eastern Pacific). Rev. Biol. Trop., 62(Suppl. 1), 65-83.

Longo-Sánchez M.C., Gómez-Aguirre A.M., Blanco J.F. and Zamora-González H., 2009. Cambios multianuales y espaciales de la composición y estructura del ensamblaje de insectos acuáticos en las quebradas perennes de la isla Gorgona, Colombia. Actual Biol., 31, 141-160.

Roldán G., 1985. Contribución al conocimiento de las ninfas de efemerópteros en el Departamento de Antioquia. Actual Biol., 14, 3-13.

Souto P.M., Da-Silva E.R. and Nessimian J.L., 2014. Two new species of Thraulodes Ulmer, 1920 (Ephemeroptera: Leptophlebiidae: Atalophlebiinae) from Southeast Brazil. Zootaxa, 3760, 571-578.

Traver J.R., 1960. Uruguayan mayflies. Family Leptophlebiidae. Part III. Rev. Soc. Uru. Entomol., 4, 73-85.

Traver J.R., 1943. New Venezuelan mayflies. Bol. Entomol. Venez., 2, 49-57. 
Traver J.R. and Edmunds G.F. Jr., 1967. A revision of the genus Thraulodes (Ephemeroptera: Leptophlebiidae). Misc. Publ. Entomol. Soc. Amer., 5, 349-395.

Vásquez G.L., Naundorf G.I. and Zamora H., 1996. Caracterización físico-química de ecosistemas dulceacuícolas del Parque Natural Nacional Isla Gorgona, Cauca. Unicauca Cienc. (Universidad del Cauca, Colombia), 1, 19-24.

Walker, F., 1853. Ephemerinae. List of the specimens of neuropterous insects in the collection of the British Museum, Part III (Termitidae-Ephemeridae), 533-585.

Zamora H., Vásquez G.L. and Naundorf G.I., 1996. Macroinvertebrados dulceacuícolas del Parque Natural
Nacional Isla Gorgona, Cauca. Unicauca Cienc. (Universidad del Cauca, Colombia), 1, 12-18.

Zúñiga M. del C., Molineri C. and Domínguez E., 2004. El Orden Ephemeroptera en Colombia. In: Andrade M.G., Amat García G. and Fernández F. (eds.), Insectos de Colombia, Vol. 3. Universidad Nacional de Colombia e Instituto Humboldt, Santafé de Bogotá, Colombia, 17-41.

Zúñiga M. del C., Cardona W., Molineri C., Mendivil J., Cultid C., Chará-Serna A.M. and Giraldo A., 2014. Entomofauna acuática del Parque Nacional Natural Gorgona, Pacífico colombiano, con énfasis en Ephemeroptera y Plecoptera. Rev. Biol. Trop., 62(Suppl. 1), 221-241. 